\title{
PEMANFAATAN LIMBAH BIJI DURIAN SEBAGAI PLASTIK BIODEGRADABLE DENGAN VARIASI SUHU GELATINASI DAN PENAMBAHAN $\mathrm{CaCO}_{3}$
}

\author{
UTILIZATION OF DURIAN SEEDS WASTE \\ BIODEGRADABLE PLASTIC WITH VARIATION OF GELATINATION \\ TEMPERATURE AND ADDITION OF $\mathrm{CaCO}_{3}$
}

\author{
Siti Fatimah, Latifah Soraya, Harimbi Setyawati* \\ Jurusan Teknik Kimia, Fakultas Teknologi Industri, ITN Malang \\ Jl. Bendungan Sigura-gura No.2 Malang 65145 \\ * arimbisetya@yahoo.co.id
}

\begin{abstract}
Abstrak
Saat ini jumlah limbah biji durian semakin meningkat seiring meningkatnya permintaan masyarakat akan buah durian. Namun belum banyak masyarakat yang dapat memanfaatkan limbah biji durian sehingga dapat mempunyai nilai jual yang tinggi. Biji durian memiliki beberapa kandungan antara lain $66,49 \%$ pati, $27,24 \%$ air, $1,19 \%$ abu dan $5,08 \%$ protein. Kandungan pati yang tinggi dalam biji durian membuat biji durian dapat dimanfaatkan lagi, salah satunya menjadi plastik biodegradable. Plastik biodegrdable merupakan plastik yang terbuat dari bahan organik dan dengan mudah dapat teruarai oleh mikroba dalam tanah. Limbah biji durian di proses mulai dari tahap penghilangan getah, pengeringan dan size reduction sampai menjadi tepung biji durian. Penelitian ini dilakukan untuk mengkaji pengaruh banyaknya filler $\left(\mathrm{CaCO}_{3}\right)$ dan variasi suhu gelatinasi.Plastik biodegradable dibuat dengan melarutkan tepung biji durian dengan aquades ditambah dengan sorbitol dan $\mathrm{CaCO}_{3}$. Selanjutnya variasi suhu gelatinasi $\left(60^{\circ} \mathrm{C}, 70^{\circ} \mathrm{C}\right.$, dan $\left.80^{\circ} \mathrm{C}\right)$ dengan $\mathrm{CaCO} 3(0,4 \% ; 0,6 \% ; 0,8 \% ; 1 \%$; dan $1,2 \%$ dari berat tepung biji durian ). Karateristik plastik biodegradable ditandai dengan adanya uji biodegradasi, uji kuat tarik, dan uji elongasi. Hasil karakterisasi plastik bioegradable yang memiliki hasil optimal untuk kuat tarik sebesar 7,1 $\mathrm{MPa}$ dengan variasi suhu $80^{\circ} \mathrm{C}$ dan $1,2 \% \mathrm{CaCO}_{3}$, untuk uji elongasi sebesar $30 \%$ dengan variasi suhu $80^{\circ} \mathrm{C}$ dan $0,4 \% \mathrm{CaCO}_{3}$. Sedangkan hasil biodegradasi sebesar $97,44 \%$ dengan variasi suhu $70^{\circ} \mathrm{C}$ dan $0,4 \% \mathrm{CaCO}_{3}$.
\end{abstract}

Kata kunci : Limbah biji durian, Plastik biodegradable, Sorbitol, $\mathrm{CaCO} 3$

\begin{abstract}
The number of waste the durian in high demand for increasing public durian fruit .But not many people can utilize the wastes of durian that have high selling values. The durian has several $66,49 \%$ starch content among others , 27,24\% water, gray and 1,19\% 5,08\% protein .High in starch content of durian seed causes durian can be used again, one become biodegradable plastic .Plastic biodegrdable is a plastic made from organic matter and can easily teruarai by microbes in soil .Waste seed durian in the process of starting from the removal of sap, drying and size reduction until it becomes the starchy durian .This research was undertaken to assess the influence of the filler $\left(\mathrm{CaCO}_{3}\right)$ and temperature variations gelatinasi.plastik biodegradable made by dissolving the starchy durian with aquades caco3 and coupled with sorbitol. In the long term the the variations of temperature gelatinasi $\left(60^{\circ} \mathrm{C}, 70^{\circ} \mathrm{C}\right.$, and $\left.80^{\circ} \mathrm{C}\right)$ with $\mathrm{CaCO}_{3} \quad(0,4 \% ; 0,6 \% ; 0,8 \% ; 1 \%$; and $1,2 \%$ of the weight durio flour $)$.Karateristik biodegradable plastic industries were the biggest characterized by the presence of the test and been approved biodegradasi, the test and been approved strong pull, and test it an elongation of an .The results of characterization plastic bioegradable that has optimum results for vigorous pull as much as 7,1 mpa with the variation of the temperature of $80^{\circ} \mathrm{C}$ and $1,2 \% \mathrm{CaCO}_{3}$, the road worthy test an elongation of an as much as $30 \%$ with the variation of the temperature of $80^{\circ} \mathrm{C}$ and $0,4 \% \mathrm{CaCO}_{3} . \mathrm{On}$ the inventory biodegradasi as much as $97,44 \%$ with the variation of the temperature of $70^{\circ} \mathrm{C}$ and $0,4 \%$ $\mathrm{CaCO}_{3}$
\end{abstract}

Keywords: Waste of durian, plastic biodegradable , sorbitol, $\mathrm{CaCO}_{3}$ 


\section{Pendahuluan}

Produksi durian di Indonesia cukup melimpah. Hal ini sejalan dengan perkembangan luas panennya (Pusat Data dan Sistem Informasi Pertanian, 2014), menunjukkan bahwa produksi durian selama tahun 1990-2013 cenderung meningkat. Pada tahun 1990 produksi durian Indonesia sebesar 242,56 ribu ton sedangkan pada tahun 2013 produksi durian telah mencapai 759,05 ribu ton dengan rata - rata pertumbuhan selama periode tersebut sebesar $8,89 \%$ per tahun. Hal ini memicu bertambahnya jumlah limbah biji durian yang dihasilkan.

Selama ini, bagian buah durian yang lebih umum dikonsumsi adalah bagian salut buah atau dagingnya. Persentase berat bagian ini termasuk rendah yaitu hanya 20-35\%. Hal ini berarti kulit (60-75\%) dan biji (5-15\%) belum termanfaatkan secara maksimal dan menjadi limbah yang merugikan. Umumnya kulit dan biji menjadi limbah yang hanya sebagian kecil dimanfaatkan sebagai pakan ternak, malahan sebagian besar dibuang begitu saja. Padahal jika diolah lebih lanjut limbah biji durian dapat bermanfaat lebih sebagai bahan baku berbagai olahan makanan yang tentunya akan memberikan nilai tambah (Prasetyaningrum, 2010). Kandungan yang terdapat dalam biji durian antara lain $66,49 \%$ pati; $27,24 \%$ air; $1,19 \%$ abu; 5,08 \% protein. Kandungan patinya ini lebih tinggi dibanding singkong 34,7\% ataupun ubi jalar 27,9\% (Haryati, 2017).

Tepung limbah biji durian dapat dihasilkan melalui dua cara yaitu menggunakan metode kering dan metode basah (ekstraksi). Proses awal di lakukan penghilangkan getah limbah biji durian terlebih dahulu dengan melakukan perendaman dengan larutan $\mathrm{CaCO}_{3}$. Pada metode kering proses pembuatan tepung dilakukan dengan cara pengeringan menggunakan oven pada suhu $50^{\circ} \mathrm{C}$ (Astuti, 2015). Untuk metode basah proses pembuatan tepung dilakukan dengan cara menambahkan aquadest pada limbah biji durian untuk dihancurkan dan diendapkan. Endapan dari kedua metode di atas dikeringkan di dalam oven pada suhu $50^{\circ} \mathrm{C}$ selama 24 jam (Cornelia, 2013).

Pada pembuatan plastik biodegradable dibutuhkan plasticizer untuk memperoleh sifat bioplastik yang khusus, pada penelitian ini digunakan sorbitol sebagai bahan plasticizer. Selain itu diperlukan juga bahan pengisi lain untuk meningkatkan kekuatan bioplastik dan mengatasi kekurangan sifat plastik biodegradable berupa kalsium carbonat $\left(\mathrm{CaCO}_{3}\right)$. Bahan pengisi ini dapat meningkatkan kekakuan plastik yang terlalu lentur serta kecenderungan bioplastik untuk bengkok (Haryati,2017).

Pemanfaatan limbah biji durian sebagai plastik biodegradable sudah mulai dikembangkan oleh peneliti sebelumnya, menurut penelitian Haryati (2017) untuk membuat plastik biodegradable memanfaatkan limbah biji durian menggunakan plasticizer giserol dan bahan pengisi $\mathrm{CaCO}_{3}$. Kemudian penelitian dari Christianty (2009) membuat biodegradable melalui pencampuran pati sagu termoplastis dan compatibilized linear low density polyethylene. Selanjutnya penelitian oleh Mustika (2014) pemanfaatan limbah kulit durian (durio zibethinus) dan kulit cempedak (artocarpus integer) sebagai plastik biodegradable. Peneliti lainnya oleh Astuti (2015) yang bertujuan untuk mengetahui pengaruh suhu pencampuran terhadap plastik biodegradable dari limbah biji durian yang dihasilkan. Semua peneliti diatas memanfaatkan pati yang terkandung di dalam bahan pengganti sebagai produk plastik biodegradable.

Tujuan dari penelitian ini adalah mengetahui pengaruh suhu gelatinasi terhadap karakteristik plastik biodegradable yang dihasilkan serta pengaruh konsentrasi filler $\left(\mathrm{CaCO}_{3}\right)$ terhadap karakteristik plastik biodegradable yang dihasilkan. Kegunaan yang dapat diambil menambah manfaat limbah biji durian yang berlimpah sekaligus meningkatkan nilai ekonominya dan memberikan gambaran tentang pemanfaatan limbah biji durian secara optimal.

\section{Teori}

Pada tahun 2017, Sri Haryati, Anggie Septia Rini, dan Yuni Safitri melakukan penilitian dengan judul, "Pemanfaatan Biji Durian sebagai Bahan Baku Plastik Biodegradable dengan Plasticizer Gliserol dan Bahan Pengisi $\mathrm{CaCO}_{3}$ ". Plastik biodegradable terbaik yang dihasilkan didapatkan pada sampel dengan penambahan 25\% gliserol dan 1,5gram $\mathrm{CaCO}_{3}$ dengan nilai kuat tarik sebesar 0,71 $\mathrm{MPa}$. Dan untuk hasil persen pemanjangan (elongasi) yang terbaik didapatkan pada sampel dengan penambahan 5 gram pati, 55\% gliserol, dan tanpa penambahan $\mathrm{CaCO}_{3}$ dengan nilai persen pemanjangan (elongasi) sebesar 16,3\% (Haryati, 2017).

Peneliti selanjutnya adalah Prima Astuti Handayani dan Hesmita Wijayanti, dengan judul, "Pembuatan Film Plastik Biodegradable dari Limbah Biji Durian (Durio Zibethinus Murr)". Film plastik biodegradable dihasilkan dari formula pati limbah biji durian, larutan kithosan dan gliserol. Pelarut yang digunakan adalah aquadest. Dengan variabel tetap : konsentrasi Khitosan $2 \%$ dan volume Gliserol $25 \%$. Sedangkan variabel berubah yang digunakan adalah suhu gelatinasi : $70{ }^{\circ} \mathrm{C}, 80 \circ \mathrm{C}$, dan $90{ }^{\circ} \mathrm{C}$.

Variasi suhu proses pengadukan mempengaruhi kemampuan kuat tarik dan elongasi, film plastik biodegradable terbaik dihasilkan pada suhu pengadukan $80^{\circ} \mathrm{C}$ dengan nilai kuat tarik sebesar $1187,732 \mathrm{~N} / \mathrm{m}^{2} \mathrm{dan}$ $\%$ elongasi sebesar 7,547\%. Sedangkan variasi suhu proses pengadukan tidak mempengaruhi kemampuan biodegradasi (Astuti, 2015). 


\section{Metodologi Penelitian}

Penelitian dilaksanakan di Laboratorium Limbah ITN Malang. Tahap penelitian adalah studi literatur, persiapan penelitian, pelaksanaan penelitian, pengumpulan data, analisa data, evaluasi dan terakhir pembuatan laporan. Berikut adalah variabel kontrol dan bebas, alat, bahan, dan prosedur dilanjutkan dengan diagram alir penelitian

\section{Bahan dan Alat Penelitian}

Bahan baku utama yang digunakan adalah limbah biji durian. Bahan-bahan penunjang yang digunakan adalah Aquadest, sorbitol, dan $\mathrm{CaCO}_{3}$. yang didapatkan di toko bahan kimia Panadia malang. Alat-alat yang digunakan dalam penelitian ini adalah oven, pengayak, termometer, neraca analitik, hot plate, stirrer dan beberapa peralatan gelas untuk kebutuhan preparasi maupun pembuatan plastik biodegradable.

\section{Prosedur Penelitian}

Tahap pertama preparasi bahan meliputi beberapa tahapan, yakni pengupasan, perendaman, dan pengeringan (drying). Limbah biji durian yang diperoleh dikupas untuk memisahkan kulit arinya dengan inti biji durian. Inti biji durian ini dipotong dengan ketebalan 0,5-1 cm. Inti biji durian direndam dalam air kapur selama 24 jam untuk mengeluarkan lendir dalam biji durian. Inti biji durian yang telah direndam, dibersihkan dengan air untuk menghilangkan lendir biji durian dan kapur yang menempel pada biji durian. Inti biji durian yang telah bersih, dikeringkan dengan menggunakan oven pada suhu $50^{\circ} \mathrm{C}$ selama 2 hari untuk menghilangkan kadar air dalam biji durian

Tahap kedua, Limbah biji durian setelah dilakukan preparasi bahan, dihaluskan menggunakan blender. Selanjutnya dilakukan pengayakan untuk mendapatkan pati limbah biji durian dengan ukuran 80 mesh yang seragam. Terakhir pati siap dipakai sebagai bahan baku pembuatan plastik biodegradable.

Tahap ketiga, Prosedur pembutan plastik biodegradable dilakukan dengan cara, pertama 10 gram pati limbah biiji durian dilarutkan ke dalam $100 \mathrm{ml}$ aquadest. Selanjutnya dilakukan pemanasan sekaligus pengadukan pada suhu yang telah ditentukan. Kemudian proses penambahan sejumlah filler $\left(\mathrm{CaCO}_{3}\right)$ ke dalam larutan pati dengan konsentrasi sesuai variabel yang telah ditentukan. Setelah larutan homogen, plasticizer (sorbitol) ditambahkan sebesar 40\% dari berat pati. Dan dilanjutkan proses gelatinasi selama 10 menit. Untuk proses pencetakan plastik biodegradable dilakukan diatas permukaan cetakkan kaca, dan dipanaskan di dalam oven dengan suhu $60^{\circ} \mathrm{C}$ selama 4 jam. Kemudian produk plastik biodegradable dikeluarkan dan didinginkan dengan suhu ruang setelah itu dilepas dari cetakan untuk dilakukan pengujian.

Tahap keempat, uji elongasi sampel plastik biodegradable di potong dengan ukuran $7 \mathrm{~cm} \times 3 \mathrm{~cm}$. Selanjutnya diletakkan pada alat Testing Machine MPY. Setelah proses analisa selesai didapatkan data besarnya \% elongasi sampel plastik biodegradable.

Tahap kelima, uji tarik sebelum dilakukan uji, terlebih dahulu sampel plastik biodegradable dipotong dengan ukuran $7 \mathrm{~cm}$ x $3 \mathrm{~cm}$. Selanjutnya proses pengukuran kuat tarik sampel menggunakan alat Testing Machine MPY. Kemudian didapatkan data besarnya kuat tarik sampel plastik biodegradable.

Tahap keenam, uji biodegradasi. Sampel yang akan dilakukan uji terlebih dahulu dipotong dengan ukuran $1 \mathrm{~cm}$ $\mathrm{x} 4 \mathrm{~cm}$. Masing-masing sampel diberi identitas atau kode, agar tidak saling tercampur nantinya. Kemudian sampel ditimbang, untuk mengetahui berat awal sampel. Selanjutnya sampel ditanam di dalam tanah, dan diamati setiap 7 hari sekali selama 14 hari. Terakhir dilakukan penimbangan masing-masing sampel setelah 14 hari ditanam di dalam tanah untuk mendapatkan persen bahan yang terdegradasi, dengan rumus :

$$
\% \text { Bahan yang terdegradasi }=\frac{\mathrm{W}_{0}-\mathrm{W}_{1}}{\mathrm{~W}_{0}} \times 100 \%
$$

Dimana:

$\begin{array}{ll}\mathrm{W}_{0} & \text { : Berat awal bahan }(\mathrm{g}) \\ \mathrm{W}_{1} & \text { : Berat Akhir bahan }(\mathrm{g})\end{array}$ 
Hasil

Data Pengamatan

Tabel 1. Data Konsentrasi $\mathrm{CaCO}_{3}$ dan Variasi Suhu Gelatinasi pada Pembuatan Plastik Biodegradable dari Limbah Biji Durian.

\begin{tabular}{|c|c|c|}
\hline Kode & Konsentrasi $\mathbf{C a C O}_{\mathbf{3}} \mathbf{( \% )}$ & Suhu Gelatinasi $\left.\mathbf{(}^{\mathbf{0}} \mathbf{C}\right)$ \\
\hline A1 & 0,4 & 60 \\
\hline A2 & 0,6 & 60 \\
\hline A3 & 0,8 & 60 \\
\hline A4 & 1 & 60 \\
\hline A5 & 1,2 & 60 \\
\hline B1 & 0,4 & 70 \\
\hline B2 & 0,6 & 70 \\
\hline B3 & 0,8 & 70 \\
\hline B4 & 1 & 70 \\
\hline B5 & 1,2 & 70 \\
\hline C1 & 0,4 & 80 \\
\hline C2 & 0,6 & 80 \\
\hline C3 & 0,8 & 80 \\
\hline C4 & 1 & 80 \\
\hline C5 & 1,2 & 80 \\
\hline
\end{tabular}

\section{Hasil Analisa Uji Kuat Tarik}

Hasil penelitian mengenai uji kuat tarik Plastik Biodegradable Limbah Biji Durian dilakukan di Laboratorium Pengujian Mutu dan Keamanan Pangan Fakultas Teknologi Pertanian Universitas Brawijaya tertera pada tabel 2.

Tabel 2. Hasil Analisa Uji Kuat Tarik

\begin{tabular}{|c|c|}
\hline Kode & Kuat Tarik (MPa) \\
\hline B1 & 1,1 \\
\hline B2 & 1,3 \\
\hline B3 & 2,1 \\
\hline B4 & 3,6 \\
\hline B5 & 4,4 \\
\hline C1 & 4,2 \\
\hline C2 & 5,4 \\
\hline C3 & 6,8 \\
\hline C4 & 6,5 \\
\hline C5 & 7,1 \\
\hline
\end{tabular}

\section{Hasil Analisa Uji Elongasi}

Hasil penelitian untuk uji kuat tarik Plastik Biodegradable dari Limbah Biji Durian dilakukan di Laboraturium Pengujian Mutu dan Keamanan Pangan Fakultas Teknologi Pertanian Universitas Brawijaya. Hasil analisa elongasi, didapatkan dalam bentuk persen (\%) dapat dilihat pada tabel III. di bawah ini.

Tabel 3. Hasil Analisa Uji Elongasi

\begin{tabular}{|l|l|}
\hline Kode & Elongasi (\%) \\
\hline B1 & 20,67 \\
\hline B2 & 17,33 \\
\hline B3 & 16,67 \\
\hline B4 & 13,33 \\
\hline B5 & 10,00 \\
\hline C1 & 30,00 \\
\hline C2 & 27,67 \\
\hline C3 & 23,33 \\
\hline C4 & 23,33 \\
\hline C5 & 16,70 \\
\hline
\end{tabular}




\section{Hasil Analisa Uji Bioderadasi}

Tabel 4. Hasil Analisa Uji Biodegradasi

\begin{tabular}{|c|c|c|c|}
\hline Kode & Berat Awal (gram) & Berat Akhir (gram) & $\begin{array}{c}\text { Sampel Terdegradasi } \\
\text { dalam 14 Hari (\%) }\end{array}$ \\
\hline B1 & 0,313 & 0,008 & 97,44 \\
\hline B2 & 0,275 & 0,014 & 94,91 \\
\hline B3 & 0,296 & 0,015 & 94,93 \\
\hline B4 & 0,252 & 0,021 & 91,67 \\
\hline B5 & 0,238 & 0,026 & 89,08 \\
\hline C1 & 0,251 & 0,012 & 95,22 \\
\hline C2 & 0,263 & 0,034 & 87,07 \\
\hline C3 & 0,265 & 0,054 & 80,00 \\
\hline C4 & 0,292 & 0,075 & 74,32 \\
\hline C5 & 0,302 & 0,085 & 71,85 \\
\hline
\end{tabular}

\section{Pembahasan}

Pembuatan plastik biodegradable dengan memanfaatkan limbah biji durian sebagai bahan baku utama menghasilkan plastik transparan yang berwarna kecoklatan pada semua sample. Warna kecoklatan ini terjadi karena adanya protein dalam pati biji durian yang cukup tinggi sehingga dapat menginduksi terjadinya reaksi pencoklatan. (Cornelia,2013).

Penelitian ini menggunakan variasi suhu gelatinasi yaitu pada suhu $60^{\circ} \mathrm{C}, 70^{\circ} \mathrm{C}$, dan $80^{\circ} \mathrm{C}$. Pada suhu gelatinasi $70^{\circ} \mathrm{C}$ dan $80^{\circ} \mathrm{C}$ hasil analisa disajikan dalam tabel 4.1.2 ; 4.1.3; dan 4.1.4. Sedangkan suhu gelatinasi $60^{\circ} \mathrm{C}$ sample rusak dan tidak dapat di analisa. Sample rusak ini terjadi karena pada suhu tersebut belum terjadi proses gelatinasi pada sample, sehingga saat di cetak sample tidak dapat membentuk plastik.

\section{Uji Kuat Tarik}

Kuat tarik merupakan gaya maksimum yang dapat ditahan oleh plastik hingga terputus. Pengujian ini bertujuan untuk mengetahui ketahanan terhadap suatu bahan terhadap pembebanan pada titik lentur dan juga untuk mengetahui keelastisan suatu bahan. Grafik 1. menunjukkan hasil uji kuat tarik plastik biodegradable.

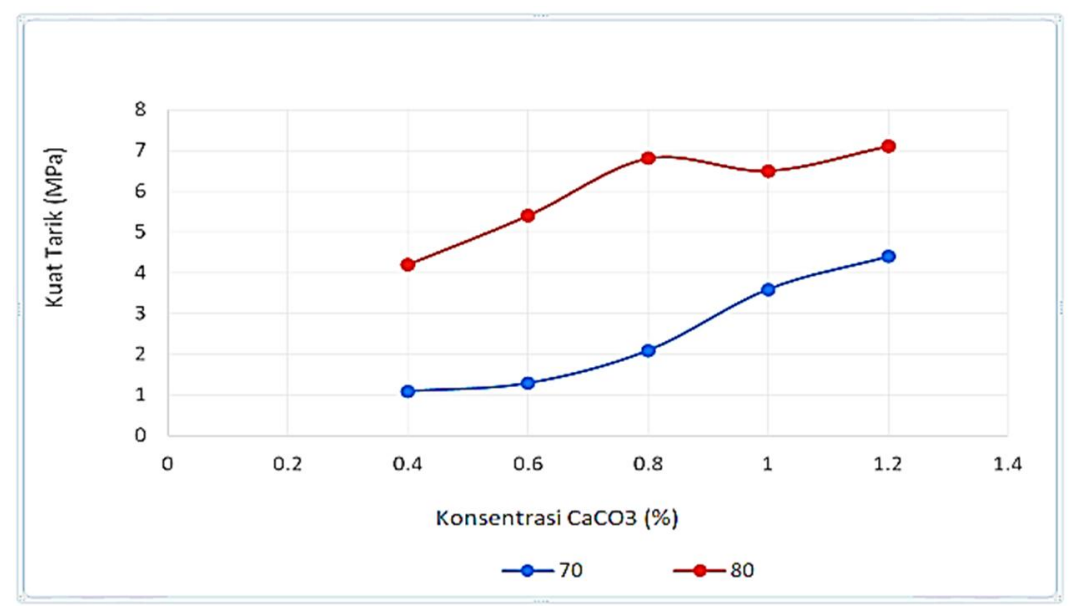

Gambar 1. Uji Kuat Tarik

Gambar 1 di atas menunjukkan bahwa penambahan konsentrasi $\mathrm{CaCO}_{3}$ yang dilakukan dapat meningkatkan nilai kuat tarik plastik biodegradable. Hal ini sesuai dengan penelitian Haryati (2017) dan Hardjono (2016) bahwa bertambah banyaknya $\mathrm{CaCO}_{3}$ yang digunakan menghasilkan nilai kuat tarik yang lebih besar pula. $\mathrm{CaCO}_{3}$ ditambahkan ke dalam matriks dengan tujuan meningkatkan sifat-sifat mekanik plastik.

Plastik biodegradable yang dihasilkan pada suhu $80^{\circ} \mathrm{C}$ nilai kuat tariknya lebih besar dari pada suhu $70^{\circ} \mathrm{C}$. Hal ini dikarenakan pada suhu $70^{\circ} \mathrm{C}$ pati biji durian belum tergelatinasi secara sempurna dan campuran plastik biodegradble masih encer sehingga mengakibatkan ikatan molekul pembentuk pati belum berikatan dengan ikatan hidrogen. Akibatnya pada proses drying plastik biodegradable terjadi retakan dan menghasilkan plastik yang retak (Astuti,2015). 
Pada sample C4 terjadi penurunan kuat tarik namun tidak signifikan. Hal ini dikarenakan pada saat proses gelatinasi, terjadi kenaikan suhu dari yang semestinya $80^{\circ} \mathrm{C}$. Ketidak konstanan suhu gelatinasi inilah yang menyebabkan ada nya penurunan nilai kuat tarik dari 6,8 MPa ke 6,5 MPa.

Nilai kuat tarik tertinggi diperoleh oleh B5 dengan nilai 4,4 dan C5 dengan nilai 7,1 MPa. Sedangkan nilai Kuat tarik terendah diperoleh oleh B1 dengan nilai 1,1 MPa dan C1 dengan nilai 4,2 MPa.. Nilai kuat tarik tersebut sesuai dengan standar plastik biodegradable yaitu antara 1-10 MPa.

\section{Uji Elongasi}

Nilai elongasi atau persen pemanjangan merupakan perubahan panjang maksimal plastik biodegradable sebelum terputus. Nilai elongasi menunjukkan kemampuan bahan kemasan plastik biodegradable untuk merenggang.

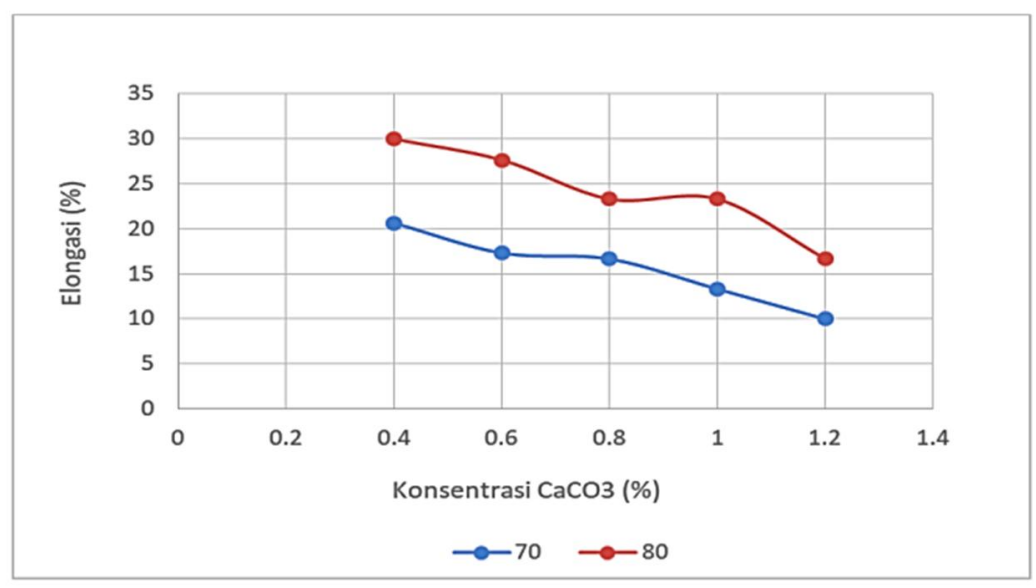

Gambar 2. Uji Elongasi

Gambar 2. menunjukkan jika penambahan konsentrasi $\mathrm{CaCO}_{3}$ sebagai filler dapat menurunkan nilai elongasi pada plastik biodegradable. Adanya bahan pengisi kalsium karbonat yang tinggi akan membuat ikatan hidrogen semakin kuat, padat, dan kaku. Hal ini disebabkan karena jarak antar molekul akan semakin rapat. Sehingga menyebabkan nilai keelastisan plastik menurun seiring dengan bertambahnya bahan pengisi yang dipakai (Haryati.2017).

Plastik biodegradable yang dihasilkan pada suhu $80^{\circ} \mathrm{C}$ nilai kuat tariknya lebih besar dari pada suhu $70^{\circ} \mathrm{C}$. Hal ini dikarenakan pada suhu $80^{\circ} \mathrm{C}$ tepung biji durian telah mengalami gelatinasi dengan ditandainya campuran plastik biodegradable yang mengental dan pencampuran plastik biodegradable telah homogen. Peristiwa gelatinasi ini kemudian diikuti plastisasi. Peryataan ini sesuai dengan penelitian Astuti (2015) bahwa nilai kuat tarik terbaik ada pada suhu $80^{\circ} \mathrm{C}$.

Nilai elongasi tertinggi diperoleh oleh B1 dengan nilai 20,67\% dan C1 dengan nilai 30,00\%. Sedangkan nilai persen elongasi terendah diperoleh oleh B5 dengan nilai 10,00\% dan C5 dengan nilai 16,70\%.

\section{Uji Biodegradasi}

Uji biodegradasi dilakukan untuk mengetahui apakah suatu bahan dapat terdegradasi dengan baik di lingkungan. Metode pengujian ini dilakukan dengan menanamkan sample plastik biodegradable didalam tanah selama 14 hari. Berikut ini disajikan hasil uji biodegradasi plastik biodegradable. 


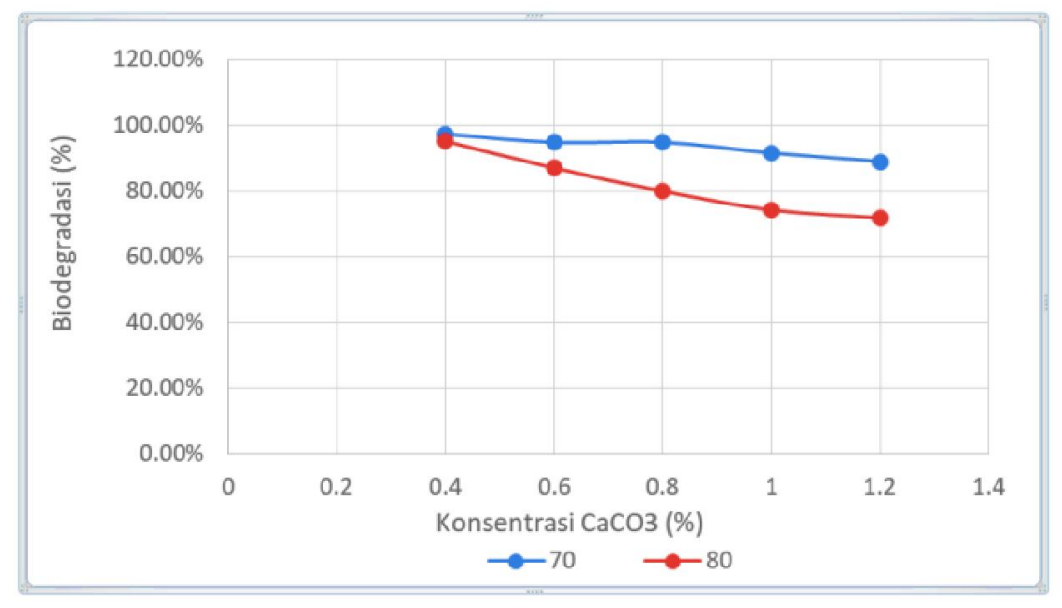

Gambar 3 Uji Biodegradasi

Gambar 3. menunjukkan semakin banyak filler $\mathrm{CaCO}_{3}$ yang ditambahkan menyebabkan penurunan persen biodegradasi. Hal ini disebabkan karena $\mathrm{CaCO}_{3}$ merupakan bahan anorganik yang tidak mudah terdegradasi.

Prosentase biodegradasi terbaik ada pada suhu $70^{\circ} \mathrm{C}$, ini disebabkan karena pada suhu $70^{\circ} \mathrm{C}$ plastik biodegradable belum tergelatinasi secara sempurna. Terlihat dari campuran yang masih belum homogen dan encer. Campuran yang demikian memmbuat pati sepenuhnya belum berikatan dengan air. Kondisi ini dapat meningkatkan kelembapan plastik sehingga menyebabkan peningkatan perkembangan bakteri dalam tanah dan mempuat plastik biodegradable dapat terdegradasi dengan baik.

Nilai biodegradasi tertinggi diperoleh oleh B1 dengan nilai 97,44\% dan C1 dengan nilai 95,22\%. Sedangkan prosentase biodegradasi terendah diperoleh oleh B5 dengan nilai 89,08 \% dan C5 dengan nilai 71,85 $\%$.

\section{Kesimpulan}

Pengaruh suhu gelatinasi $60^{\circ} \mathrm{C}$ tidak dapat menghasilkan plastik biodegradable, suhu gelatinasi $70^{\circ} \mathrm{C}$ dapat menghasilkan persen biodegradasi tertinggi, dan suhu gelatinasi $80^{\circ} \mathrm{C}$ dapat menghasilkan sifat mekanik paling baik. Sedangkan pengaruh konsetrasi filler $\left(\mathrm{CaCO}_{3}\right)$ yang tinggi akan meningkatkan nilai kuat tarik, menurunkan nilai persen elongasi, serta menurunkan nilai degradasi plastic.

\section{Daftar Pustaka}

Astuti Handayani, Prima. 2015. Pembuatan Film Plastik Biodegradable Dari Limbah Biji Durian (Durio Zibethinus Murr). Fakultas Teknik. Universitas Negeri Semarang. Semarang.

Christianty, Maria Ulfa. 2009. Produksi Biodegradable Plastic Melalui Pencampuran Pati Sagu Termoplastis Dan Compatibilized Linear Low Density Polyethylene. Pascasarjana. Institut Pertanian Bogor. Bogor.

Cornelia, Melanie. 2013. Pemanfaatan Pati Biji Durian (Durio Zibethinus Murr.) Dan Pati Sagu (Metroxylon Sp.) Dalam Pembuatan Bioplastik. ). Doctoral Student. Bogor Agricultural University. Bogor.

Haryati, Sri. 2017. Pemanfaatan Biji Durian Sebagai Bahan Baku Plastik Biodegradable Dengan Plasticizer Giserol Dan Bahan Pengisi $\mathrm{CaCo}_{3}$. Fakultas Teknik. Universitas Sriwijaya. Palembang.

Mustika Amaliyah, Desi. 2014. Pemanfaatan Limbah Kulit Durian (Durio Zibethinus) Dan Kulit Cempedak (Artocarpus Integer) Sebagai Edible Film. Balai Riset dan Standardisasi Industri. Banjarbaru.

Prasetyaningrum, A. 2013. Kelayakan Biji Durian Sebagai Bahan Pangan Alternatif : Aspek Nutrisi Dan Tekno Ekonomi. Fakultas Teknik. Universitas Diponegoro. Semarang.

Pusat Data dan Sistem Informasi Pertanian. 2014. Outlook Komoditi Durian. Sekretariat Jenderal Kementerian Pertanian. Jakarta.

Puspita, Ajeng Dian. 2013. Pembuatan Dan Karakterisasi Struktur Mikro Dan Sifat Termal Film Plastik Berbahan Dasar Pati Biji Nangka (Artocarpus Heterophyllus). Fakultas Matematika Dan Ilmu Pengetahuan Alam. Universitas Negeri Semarang. Semarang. 